\title{
DETERMINANTS OF THE ELDERLY EMPLOYMENT IN LATVIA
}

\author{
Janis Kudins ${ }^{1}$, Ph.D.
}

${ }^{1}$ Daugavpils University

\begin{abstract}
In Latvia, from 2011 to 2020 the number of people $65+$ increased by $2.7 \%$, but the number of the employed people $65+$ increased by $94.4 \%$. The aim of this research is to identify the determinants of the elderly employment in the context of active ageing. The author analysed secondary data collected by the international and Latvia's institutions as well as by Latvia's researchers who have studied the elderly. The results of these studies and the data of Latvia's statistics show that the rapid growth of the elderly employment in Latvia is more likely not an indicator of active ageing, but the elderly's attempt to overcome poverty. $60.3 \%$ of the elderly in Latvia continue to work in order to increase their current income, and only $10.2 \%$ - for non-financial reasons, which is one of the lowest values in the EU. The gap between the average income of Latvia's population and the income of people 65+ is increasing over the past 10 years. The elderly in Latvia work mainly in education and health care. These sectors have relatively lower average wages and are therefore less attractive to young people, so the elderly employment in them shows not only the importance of knowledge and experience, but also the difficulties in attracting new employees. The author concludes that Latvia is still far from real active ageing, which is typical for the most competitive EU countries. In order to move in this direction, it would be useful to use the experience of the EU's active ageing initiatives.
\end{abstract}

Key words: elderly employment, active ageing, poverty, Latvia.

JEL code: J14, J16, I38.

\section{Introduction}

Overview report "The Active Ageing Challenge for Longer Working Lives in Latvia" of the World Bank states that "significant challenges confront Latvia in ensuring that its ageing population achieve healthy, productive, and longer lives" (World Bank, 2021: 4). Healthy, productive, and longer lives of elderly people are elements of the concept of active ageing widely discussed in the modern political and scientific space (World Health Organization, 2002; Special Eurobarometer 378, 2012; Cabinet of Ministers of the Republic of Latvia, 2016; Liotta et al., 2018; AGE Platform Europe, 2021).

The results of the analysis of Latvia's official statistical data over the past 10 years show that in the period from 2011 to 2020 the number of people 65 years old and more (so called 65+) increased from 381140 persons to 391413 persons, i.e., by $2.7 \%$. In turn, the number of the employed people 65+ increased from 21009 persons to 40825 persons, i.e., by $94.4 \%$ or almost 2 times. As a result, growth of the employment rate of people $65+$ in Latvia was $4.9 \%$ or almost 2 times for 10 years: from $5.5 \%$ in 2011 to $10.4 \%$ in 2020 (the author's calculations based on the Central Statistical Bureau of Latvia, 2021a, 2021b, for more details see Table 1 below). It would seem that such rapid growth of elderly employment in Latvia is a favorable trend, indicating an active ageing and corresponding to the government priority of the elderly employment (inclusive labour market). This priority is declared in the conceptual report of the Cabinet of Ministers "Active Ageing Strategy for Longer and Better Working Lives in Latvia" prepared after holding discussions with social partners and ministries involved (Cabinet of Ministers of the Republic of Latvia, 2016).

However, the analysis of scientific publications and analytical reports of the international organizations carried out by the author of the article made him doubt the unambiguous favorableness of the growing trend of the employment rate of people 65+ in Latvia. For instance, according to the information provided by OECD report "Pensions at a Glance 2019: How Does Latvia Compare?", in 2016, "people older than 65 in Latvia had low disposable income: $29 \%$ lower on average than the total population while it is $13 \%$ lower on average in the OECD" (OECD, 2019: 1). In turn, the above mentioned overview report of the 
World Bank states that "Latvia scores high on employment among older groups - partly due to relatively low pensions" (World Bank, 2021: 4). Moreover, there is a concern that the excessive protection of elderly employment may deprive the youth of employment opportunities (Kondo, 2016), although the socioeconomic consequences of the growth of elderly employment will not be explored in this article.

Research aim, hypothesis and methods: The aim of this research is to identify the determinants of the elderly employment in the context of active ageing. The author supposes that among these determinants, the dominant is not the orientation of the elderly in Latvia towards active ageing, but, most likely, the challenge of poverty. In order to test this hypothesis, the author will use the monographic method as well as the analysis of empirical data. Empirical data for this research are the secondary data - both statistical and sociological - collected and published by international and Latvia's institutions and organizations (OECD, World Bank, World Economic Forum, World Health Organization, Eurobarometer, AGE Platform Europe, Central Statistical Bureau of Latvia) as well as Latvia's researchers who have studied different aspects of the elderly life in Latvia (Grinfelde, 2010; Opmane, 2018; Kudins, 2020).

\section{Research objectives are the following:}

1) to investigate the current trend of the elderly employment in Latvia in comparison with the general EU trend;

2) to analyse reasons for continuing to work of the elderly in Latvia in comparison with other EU countries;

3) to find the specific determinants of the elderly employment in Latvia;

4) to define, if the elderly employment in Latvia is in line with the concept of active ageing.

Research object is the elderly of Latvia. Within the framework of this study, elderly people are defined based on the following three criteria: 1) receiving an old-age pension; 2) the availability of statistical data for the selected age group; 3 ) the world practice in defining the elderly. Latvia is in the process of increasing the statutory retirement age. In Latvia, the standard (legal) retirement age for men and women, starting from 2014, increases gradually from 62 years by 3 months per year, until reaching 65 years in 2025 (Cabinet of Ministers of the Republic of Latvia, 2016). It is this age group - 65 years and older - that is also present in the official Latvia's statistics (Central Statistical Bureau of Latvia, 2021a, 2021b. 2021c). Most countries have accepted the chronological age of 65 years as a definition of the 'elderly' or older person (Orimo et al., 2006; Alpteker, 2012). Thus, the object of this study is the inhabitants of Latvia 65 years old and more (65+ age group) - in 2020 there were 391413 people (Central Statistical Bureau of Latvia, 2021a). The period of this research is limited to the last 10 years - from 2011 to 2020, which is a sufficient time interval for understanding the current situation with elderly employment in Latvia.

Research novelty: The novelty of this research is the investigation of the reasons for the rapidly increasing the elderly employment in Latvia, looking at this process 'from the inside', i.e. from the country itself. This allows the author to take into account such factors that are not always clear and visible to representatives of international organizations who have studied the reasons for the elderly employment in the EU countries (for instance, European Commission, 2016).

Research methodology: Methodologically, the author is based on a position that casts doubt on the unequivocal favorableness of the growth of the elderly employment. The author's adherence to this methodological position is explained, firstly, by the decline in the role and subjective significance of work as a type of activity and as a life value in a modern world. This issue became the main theme of the book by the British economist and political analyst D. Susskind, "A World without Work: Technology, Automation and How We Should Respond" (Susskind, 2020). And, secondly, results of the study of Daugavpils 
University's scientists show that "in the $21^{\text {st }}$ century, the proportion of people working more than 40 hours per week has been rapidly decreasing in Latvia - from $33 \%$ of all employees in 2002 to $5 \%$ of all employees in 2019. There is a rather large proportion of Latvia inhabitants working part-time, who as a reason for underemployment indicate their unwillingness to work full-time. Over the past decade, the unwillingness to work full-time in Latvia has been growing. An analysis of the results of the World Values Survey also allows the authors to conclude that the perception of work as a significant life value in the modern world is gradually, but steadily decreasing" (Menshikov et al., 2020: 18). Taking into account the current trend of decreasing the value of work as an economic activity, the rapid growth of the elderly employment looks ambiguous. Thus, it would be advisable to comprehensively study its causes, relying on the scattered previous experience of studying this issue by international organizations and offering the author's vision 'from the inside', being a resident of Latvia.

\section{Research results and discussion}

The author begins presenting the results of this research with a more detailed analysis of statistical data confirming the existence of a trend of rapid growth of the elderly employment in Latvia over the past 10 years.

Table 1

Statistical trends of elderly* number and their employment in Latvia, 2011-2020

\begin{tabular}{|l|c|c|c|}
\hline \multicolumn{1}{|c|}{ Year } & $\begin{array}{c}\text { Elderly number, } \\
\text { Absolute meaning }\end{array}$ & $\begin{array}{c}\text { Employed elderly number, } \\
\text { absolute meaning }\end{array}$ & $\begin{array}{c}\text { Elderly employment } \\
\text { rate, } \%\end{array}$ \\
\hline 2011 & 381140 & 21009 & 5.5 \\
\hline 2012 & 379546 & 23847 & 6.3 \\
\hline 2013 & 379784 & 27351 & 7.2 \\
\hline 2014 & 381615 & 26013 & 7.8 \\
\hline 2015 & 385076 & 28125 & 8.0 \\
\hline 2016 & 386585 & 30947 & 8.5 \\
\hline 2017 & 387909 & 32953 & 9.3 \\
\hline 2018 & 388856 & 36025 & 10.2 \\
\hline 2019 & 388979 & 39704 & 10.4 \\
\hline 2020 & 391413 & 40825 & $+4.9 \%$ \\
\hline Changes & $+2.7 \%$ & $+94.4 \%$ & 7.3 \\
\hline $2020 / 2011$ & & & \\
\hline
\end{tabular}

* 'Elderly' in this study means people 65 years of age and older (Orimo et al., 2006; Alpteker, 2012)

\section{Source: the author's calculations based on the Central Statistical Bureau of Latvia, 2021a, 2021b}

As the data presented in Table 1 shows, over the past 10 years, the number of Latvia residents who have reached the age of 65 has increased by almost $3 \%$. At the same time, the employment of older people 65+ has almost doubled (Table 1). It is interesting that the trend of a rapid growth of the elderly employment is typical not only for Latvia, but also for the EU as a whole. The data by the report "Ageing Europe: Looking at the Lives of Older People in the EU" shows that during 2004-2019, "the number of people employed increased at its fastest pace among people aged 60-64 years, with the total number of employed people in this age group more than doubling (up 139\%); the number of people aged 65-69 years who were employed also increased at a rapid pace, rising by 99 \%" (European Union, 2020: 91). 
The question arises as to what are the determinants of such a rapid growth of the elderly employment in Latvia in comparison with other EU countries: the desire for active ageing, an attempt to overcome poverty, or something else?

According to the methodology applied in the research of the European Commission "Employment of Older Workers", the main reasons for staying in work are divided into two groups: financial - to increase entitlement to a larger pension by working more years or to supplement household income or both - and non-financial (European Commission, 2016). The data of the following table shows the proportion of people from different EU countries aged 65-69 receiving a pension and economically active reporting different reasons for continuing to work.

As the data presented in Table 2 shows, not only Latvia, but all three Baltic states have a relatively low proportion of the elderly who continue to work for non-financial reasons. The situation with non-financial motivation for the elderly employment is worse than in Latvia only in Estonia, Greece and Romania (see Table 2). In the following figure, the author visualized the reasons for the elderly employment in Latvia in comparison with the EU average values. The data shows the clear dominance of financial reasons for the elderly employment in Latvia, namely, the need to increase their current income (in Latvia, this is the main determinant for the elderly employment - 60.3\% (Table 2), which is per $20 \%$ higher than in the EU average (Figure 1)). 
Reasons for continuing to work of the elderly in the EU countries, 65-69 age group, \%, 2012

\begin{tabular}{|c|c|c|c|c|}
\hline \multirow{2}{*}{ Country } & \multicolumn{3}{|c|}{ Financial reasons for continuing to work } & \multirow{2}{*}{$\begin{array}{l}\text { Non-financial reasons } \\
\text { for continuing to work }\end{array}$} \\
\hline & $\begin{array}{l}\text { To increase } \\
\text { pension }\end{array}$ & $\begin{array}{l}\text { To increase } \\
\text { income }\end{array}$ & $\begin{array}{l}\text { To increase } \\
\text { both }\end{array}$ & \\
\hline Denmark & 0.5 & 6.0 & 4.3 & 89.2 \\
\hline Spain & 0.0 & 16.2 & 0.0 & 83.8 \\
\hline Slovenia & 2.3 & 16.5 & 1.9 & 79.4 \\
\hline Netherlands & 0.3 & 21.4 & 2.9 & 75.4 \\
\hline Sweden & 6.1 & 10.1 & 8.9 & 75.0 \\
\hline Austria & 1.3 & 24.7 & 1.4 & 72.6 \\
\hline Luxembourg & 0.0 & 24.3 & 3.7 & 72.0 \\
\hline Finland & 5.7 & 14.3 & 8.4 & 71.6 \\
\hline Belgium & 3.3 & 29.1 & 1.3 & 66.4 \\
\hline Ireland & 2.6 & 29.7 & 10.2 & 57.5 \\
\hline United Kingdom & 3.0 & 28.9 & 12.0 & 56.1 \\
\hline Malta & 6.7 & 30.4 & 13.3 & 49.6 \\
\hline Germany & 2.5 & 45.2 & 3.8 & 48.5 \\
\hline France & 4.0 & 52.2 & 0.0 & 43.8 \\
\hline Cyprus & 1.2 & 44.8 & 19.0 & 35.0 \\
\hline Italy & 6.9 & 49.1 & 9.7 & 34.3 \\
\hline Portugal & 2.0 & 62.4 & 4.3 & 31.3 \\
\hline Croatia & 0.0 & 71.4 & 0.0 & 28.6 \\
\hline Poland & 5.0 & 47.7 & 20.5 & 26.9 \\
\hline Czechia & 5.4 & 48.0 & 22.3 & 24.3 \\
\hline Bulgaria & 6.1 & 66.3 & 11.7 & 15.9 \\
\hline Hungary & 2.0 & 66.3 & 16.4 & 15.3 \\
\hline Slovakia & 3.5 & 73.2 & 9.1 & 14.2 \\
\hline Lithuania & 12.3 & 52.6 & 21.9 & 13.3 \\
\hline Latvia & 16.1 & 60.3 & 13.4 & 10.2 \\
\hline Estonia & 6.6 & 82.4 & 1.1 & 10.0 \\
\hline Greece & 0.9 & 88.0 & 3.3 & 7.7 \\
\hline Romania & 3.7 & 93.0 & 1.8 & 1.6 \\
\hline
\end{tabular}

Notes:

1) Countries ranged by the author in descending order according to the proportion of non-financial reasons for continuing to work

2) Figures in italics relatively uncertain because of small number of observations

Source: the author's compilation based on the European Commission, 2016: 30 


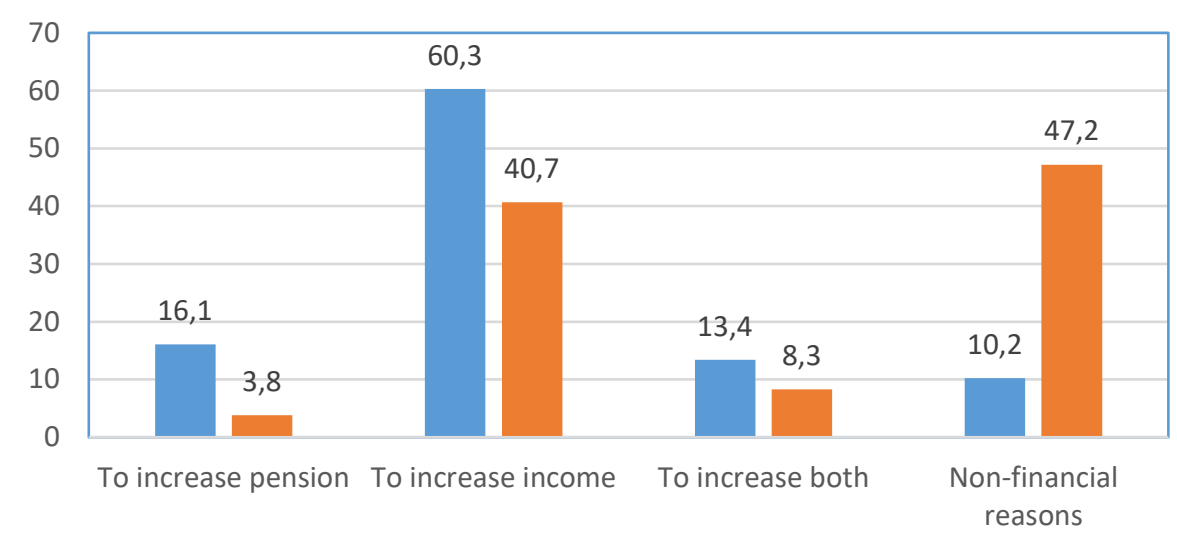

- Latvia $\quad$ EU average

Source: the author's compilation based on the European Commission, 2016: 30

Fig. 1. Comparison of reasons for continuing to work of the elderly in Latvia with the EU average proportions, 65-69 age group, \%, 2012

Based on the data presented in Table 2, it is possible to suppose that the share of non-financial reasons in the total 'reasons portfolio' strongly correlates with the level of economic development of a country, since the largest share of non-financial reasons for employment of the elderly is observed in such economically developed countries as Denmark, Netherlands, Sweden, Austria. For empirical confirmation of this assumption, it is necessary to conduct a correlation analysis for assessing interconnection between selected reasons for continuing to work of the elderly in the EU countries and competitiveness of these countries, which is measured by the Global Competitiveness Index (Schwab, 2013).

Table 3
Interconnection between selected reasons for continuing to work of the elderly in the EU countries and competitiveness of these countries, Pearson correlation coefficient, $n=28$ countries, 2012

\begin{tabular}{|c|c|c|c|}
\hline \multirow{2}{*}{$\begin{array}{l}\text { Selected reasons for } \\
\text { continuing to work of } \\
\text { the elderly }\end{array}$} & \multirow[b]{2}{*}{ Correlation variables } & \multicolumn{2}{|c|}{ Global Competitiveness Index (GCI) } \\
\hline & & $\begin{array}{l}\text { Rank*, out of } 148 \\
\text { countries }\end{array}$ & Score, 1-7 \\
\hline \multirow{2}{*}{ To increase income } & $\begin{array}{l}\text { Pearson correlation } \\
\text { coefficient, } \mathbf{r}\end{array}$ & $-0.710 * *$ & $+0.707 * *$ \\
\hline & $\begin{array}{l}\text { Statistical significance of } \\
\text { the correlation, } p \text {-value }\end{array}$ & 0.000 & 0.000 \\
\hline \multirow{2}{*}{ Non-financial reasons } & $\begin{array}{l}\text { Pearson correlation } \\
\text { coefficient, } \mathbf{r}\end{array}$ & $+0.735^{* *}$ & $-0.694 * *$ \\
\hline & $\begin{array}{l}\text { Statistical significance of } \\
\text { the correlation, } \mathrm{p} \text {-value }\end{array}$ & 0.000 & 0.001 \\
\hline
\end{tabular}

\footnotetext{
* Lower rank means higher competitiveness

** statistically significant correlation, with 99\% probability
}

Source: the author's compilation based on the European Commission, 2016: 30 and Schwab, 2013

As the data presented in Table 3 shows, the higher a country's position in the global competitiveness rankings, the less often the elderly in that country continue to work to increase their income $(r=-0.710 * *$, $p=0.000)$ and, accordingly, more often work for non-financial reasons $(r=-0.735 * *, p=0.000)$. Almost the same situation is with the correlation between the selected reasons for continuing to work of the elderly and the GCI score (Table 3). Thus, it can be argued that active ageing in the form of employment for non-financial reasons is a phenomenon that is more typical for countries with a relatively higher level of 
competitiveness. Although, there are some exceptions - for instance, Slovenia with $62^{\text {nd }}$ rank of the competitiveness out of 148 countries of the world (Schwab, 2013), but very high share of those elderly, who continue to work by non-financial reasons, - 79.4\%, which is the $3^{\text {rd }}$ rank out of 28 EU countries (Table 2). In turn, Germany with 4th rank of the competitiveness out of 148 countries of the world (Schwab, 2013) does not show a high share of those elderly, who continue to work by non-financial reasons, $-48.5 \%$, which is only the $13^{\text {th }}$ rank out of 28 EU countries (Table 2).

The author supposes that a type of reasons - financial or non-financial - for continuing to work of the elderly have to be taken into consideration in development of the Active Ageing Index (AAI), which measures the level to which older people live independent lives, participate in paid employment and social activities as well as their capacity to actively age (European Commission, 2021).

The data of the Central Statistical Bureau of Latvia indicates a decrease in the income of the elderly in Latvia compared to the average income of the population of Latvia over the past 10 years. Although the income of the elderly in Latvia increased between 2011 and 2019, the average income of Latvia's population increased faster. As a result, the gap between the average income of Latvia's population and the income of people $65+$ is constantly increasing (Figure 2 ).

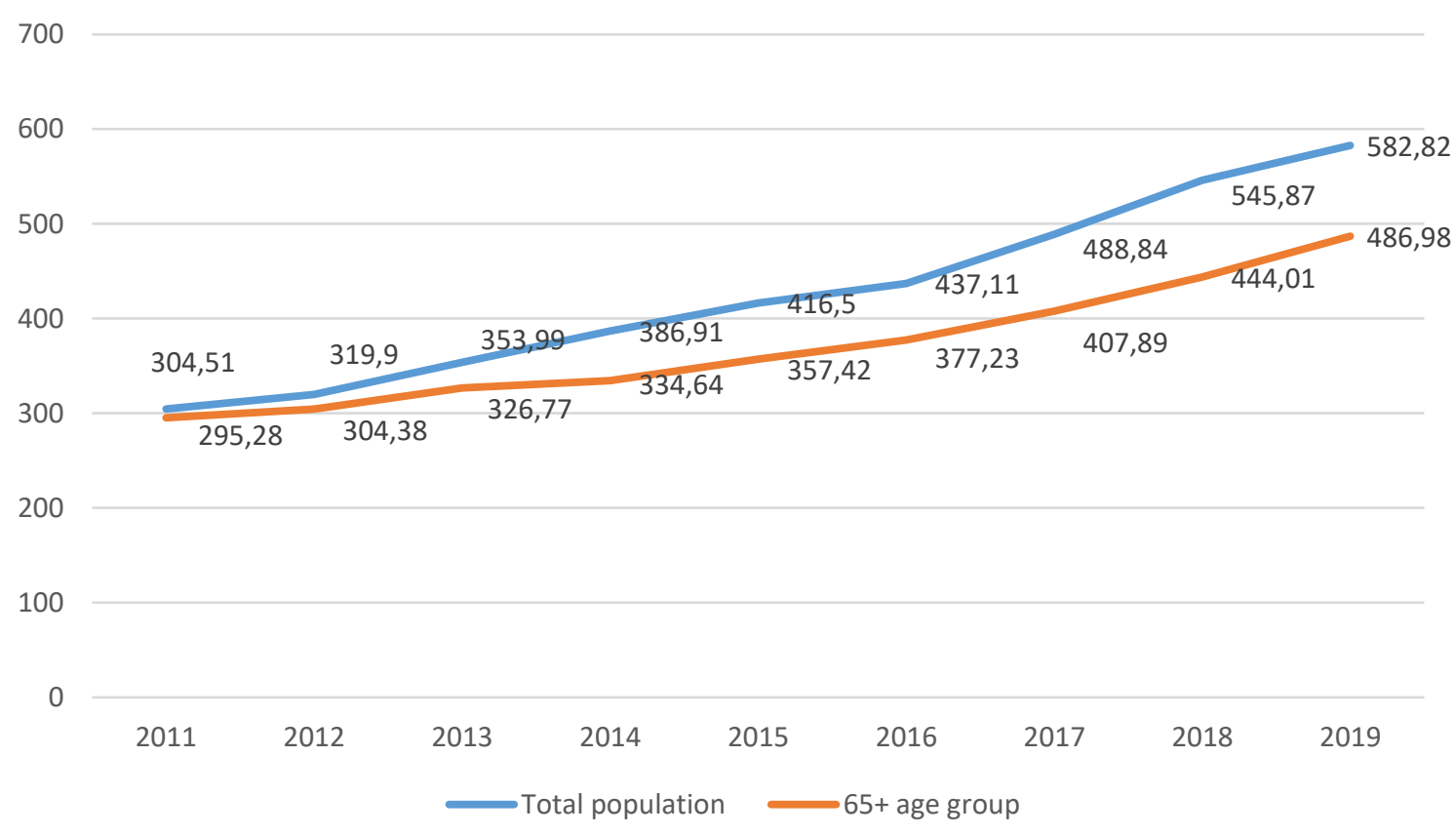

Source: the author's compilation based on the Central Statistical Bureau of Latvia, 2021c

Fig. 2. Comparison of the mean disposable income per household member between the total population of Latvia and 65+ age group, euro per month, 2011-2019

Comparison of statistical data on the increase in disposable income per household member for the period from 2011 to 2019 by age groups of the population of Latvia allows the author to conclude that the $65+$ age group lags behind most in terms of income growth, since income growth in this age group over the past 10 years the lowest (Table 4). According to the previous research findings by the author, "the amount of pension is a significant economic factor, which impacts the labor supply of older people" (Kudins, 2020: 206). 
Mean disposable income per household member by age group in Latvia, euro, 2011 and 2019

\begin{tabular}{|l|l|l|c|}
\hline $\begin{array}{c}\text { Age } \\
\text { groups }\end{array}$ & $\mathbf{2 0 1 1}$ & $\mathbf{2 0 1 9}$ & Changes 2019/2011, \% \\
\hline $0-15$ & 255.25 & 512.35 & +100.7 \\
\hline $16-24$ & 276.21 & 557.89 & +102.0 \\
\hline $25-34$ & 344.28 & 702.73 & +104.1 \\
\hline $35-44$ & 308.32 & 622.65 & +101.9 \\
\hline $45-54$ & 314.03 & 634.64 & +102.1 \\
\hline $55-64$ & 346.16 & 627.82 & $+\mathbf{6 4 . 9}$ \\
\hline $\mathbf{6 5 +}$ & $\mathbf{2 9 5 . 2 8}$ & $\mathbf{4 8 6 . 9 8}$ & +91.4 \\
\hline Total & 304.51 & 582.82 & +4 \\
\hline
\end{tabular}

Source: the author's calculations based on the Central Statistical Bureau of Latvia, 2021c

Latvia's researcher A. Grinfelde in her Doctoral Thesis "Life Quality of Pensioners in Latvian Regions" argued that "pensioners' perceptions of a good life in Latvia are mainly associated with material provision, good health and good relationships with the closest people: family members, friends and neighbours" (Grinfelde, 2010: 90). She also found that the poorest Latvia's pensioners live in Latgale region and Vidzeme region. Four out of ten pensioners in Vidzeme region and five out of ten pensioners in Latgale region cannot afford one of the following goods: telephone, colour TV, washing machine, and car. More than a half of pensioners in Vidzeme region (54.8\%) and Latgale region (59.7 \%) live in inadequate or not well-facilitated lodging, comparing to Pieriga region, where pensioners are twice less unsatisfied with housing condition. Material unsafety is intensified by the fact that $92 \%$ of those living in Latgale region and Vidzeme region barely can 'make the ends meet' (Grinfelde, 2010).

Thus, both the results of studies of international organizations and the data of official Latvia's statistics show that the rapid growth in the elderly employment in Latvia over the past 10 years is more likely not an indicator of active ageing of these people, but their attempt to overcome the poverty that threatens them. Another indirect evidence of this fact is contained in the results of a research conducted by the Bank of Latvia on the shortage of laborforce in Latvia and the possibility of replenishing it with the help of employed pensioners (Opmane, 2018). Analyzing the results of this research, I. Opmane, an economist at the Bank of Latvia, is stressed the major sectors popular with pensioners - education and health care. These sectors can be seen as areas where the education and experience of employees is a bonus, so seniors have an advantage that is often used. However, it should be noted that these sectors have relatively lower average wages and are therefore less attractive to young people, so the elderly employment in them shows not only the importance of knowledge, but also the difficulties in attracting new employees (Opmane, 2018).

Relatively more seniors are employed in agriculture, noting both the age distribution of those living in rural areas and the fact that agriculture can also be a way of life, which is characterized by continuing the usual work even reaching retirement age. However, it should be noted that, compared to new employees, seniors are more often skilled agricultural workers than simple physical ones - thus, their experience and knowledge is used more than the physical force. Also, in general, relatively fewer seniors work in sectors related to heavier physical work (construction, transportation and storage) or the use of the new technologies (information and communication services) (Opmane, 2018). 
However, there is another reason for the elderly employment, related to the culture of financial behavior of the inhabitants of Latvia, which, according to the author of this article, does not fall into the field of view of international organizations studying the elderly employment in Latvia. In December 2011, the SEB Bank conducted a sociological survey "On the Latest Trends in Pensions", which was realized in an electronic environment (answers were given by 1450 respondents). According to the data of this survey, almost a half ( $48 \%$ ) of the residents of Latvia, looking at the active travelling of foreign pensioners, admit that it is important to build up pension savings in a timely manner, but only $33 \%$ of the residents of Latvia are ready to make savings to increase their material well-being in retirement years. In addition, the share of the population who believe that they will continue to work at retirement age has increased from $17 \%$ to 19 \% during the year (SEB Bank, 2012). Based on this data, K. Martinsone, SEB Bank's manager of the projects of external communication, concludes that "the residents of Latvia prefer to work in old age than to make pension savings today" (SEB Bank, 2012).

Thus, the data of the studies analysed by the author, as well as statistical data over the past 10 years, indicate that Latvia's government and policy-makers are facing a difficult dilemma. On the one hand, increasing the elderly employment is a priority for the active ageing policy, and it is also necessary to fill the laborforce shortage in the Latvia's labor market. On the other hand, the main incentive for the elderly employment in Latvia is their poverty. In such a situation, an increase in pensions will lead to a decrease in the elderly employment, which does not correspond to either the framework of the active ageing policy or the needs of the Latvia's economy.

\section{Conclusions, proposals, recommendations}

1) Over the past 10 years, Latvia has a rapid - almost 2 times - increase in the elderly (65+) employment, which quantitatively corresponds to the general EU's trend. In turn, the reasons why the elderly in Latvia continue to work at retirement age are quite different from the motivation of the elderly in many other EU countries - especially in such countries, as Denmark, Sweden, Finland, etc.

2) The main reason for the elderly employment in Latvia is the need to 'make the ends meet' (especially at Vidzeme region and Latgale region of Latvia), and does not indicate the aspiration of older Latvia's residents to active ageing and self-realization via the work. In addition, the Latvia's economy is also interested in the elderly employment, especially in education and health care, where it is difficult to attract young workers.

3) According to the author, one of the reasons for the elderly employment in Latvia is deeply rooted in the habits and culture of financial behavior of Latvia's residents. These habits and culture of financial behavior has been formed over generations and has a rational background from the point of view of adapting previous generations of Latvia's residents to the financial and economic conditions of life in a planned economy. As a result, at the moment the residents of Latvia prefer to work in old age than to make pension savings today, and such a life pattern cannot be changed in the short term.

4) The author supposes that Latvia is still far from real active ageing, which is typical for the most competitive EU countries. Nevertheless, in order to move in this direction, it would be useful for Latvia's society to study and, if possible, to use the experience of the EU's active ageing initiatives - for instance, "Older People for Older People" (Northern Europe Periphery Programme), "Retired and Senior Volunteer Programme - Retire into Action" (the UK programme), "The Campaign to End Loneliness" (the UKwide initiative) and others (AGE Platform Europe, 2021). 


\section{Bibliography}

1. AGE Platform Europe. (2021). Active Ageing in the Community. Retrieved: https://www.age-platform.eu/goodpractice/active-ageing-community. Access: 28.03.2021.

2. Alpteker, H. (2012). Who is Elderly? Retrieved: https://www.researchgate.net/post/Who-is-elderly. Access: 28.03.2021.

3. Cabinet of Ministers of the Republic of Latvia. (2016). Active Ageing Strategy for Longer and Better Working Life in Latvia. Conceptual Report. Retrieved: http://www.Im.gov.Iv/upload/politika/Imzin_aktnovec.pdf. Access: 28.03.2021.

4. Central Statistical Bureau of Latvia. (2021a). Table IRD010: Population under, of and over Working Age in Regions, Cities, 21 Development Centres and Municipalities at the Beginning of the Year by Territorial Unit, Sex, Age Group, Indicator and Time Period. Statistical Database. Retrieved: https://data.stat.gov.Iv/pxweb/en/OSP_PUB/START_POP_IR__IRD/IRD010/. Access: 28.03.2021.

5. Central Statistical Bureau of Latvia. (2021b). Table NBL020c: Employed and Employment Rate by Age Group, Sex by Sex, Age Group, Indicator and Time Period. Statistical Database. Retrieved: https://data.stat.gov.Iv/pxweb/en/OSP_PUB/START_EMP_NB_NBLA/NBL020c/. Access: 28.03.2021.

6. Central Statistical Bureau of Latvia. (2021c). Table MIS070: Mean Disposable Income per Household Member by Age Group and Time Period. Statistical Database. Retrieved: https://data.stat.gov.Iv/pxweb/en/OSP_PUB/START_POP_MI_MIS/MIS070/. Access: 28.03.2021.

7. European Commission. (2016). Employment of Older Workers. Research Note no. 5/2015.

8. European Commission. (2021). Active Ageing Index: Monitoring Active and Healthy Ageing in the EU. Retrieved: https://composite-indicators.jrc.ec.europa.eu/active-ageing-index/active-ageing-index. Access: 28.03.2021.

9. European Union. (2020). Ageing Europe: Looking at the Lives of Older People in the EU. Luxembourg: Publications Office of the European Union.

10. Grinfelde A. (2010). Life Quality of Pensioners in Latvian Regions. Doctoral Thesis. Jelgava: Latvia University of Agriculture.

11. Kondo, A. (2016). Effects of Increased Elderly Employment on Other Workers' Employment and Elderly's Earnings in Japan. IZA Journal of Labor Policy, Vol. 5. DOI: 10.1186/s40173-016-0063-z

12. Kudins, J. (2020). Involvement of Older People in Employment in Latvia. Proceedings of the 2020 International Conference "Economic Science for Rural Development", No. 53, pp. 201-207.

13. Liotta, G., Canhao, H., Cenko, F., Cutini, R., Vellone, E., Illario, M., Kardas, P., Poscia, A., Sousa, R.D., Palombi, L., Marazzi, M.C. (2018). Active Ageing in Europe: Adding Healthy Life to Years. Front Med (Lausanne), Vol. 5, p. 123. DOI: $10.3389 /$ fmed.2018.00123

14. Menshikov, V., Kokina, I., Komarova, V., Korshenkov, E. (2020). Human-Machine Collaboration as a Factor of Labour Productivity and Efficiency. European Scientific Journal. Vol. 16, No. 13, pp. 1-23. DOI: $10.19044 /$ esj.2020.v16n13p1

15. OECD. (2019). Pensions at a Glance 2019: How Does Latvia Compare? Retrieved: https://www.oecd.org/latvia/PAG2019-LVA.pdf. Access: 28.03.2021.

16. Opmane, I. (2018). Latvija trukst darbaspeka. Vai pensionari var palidzet? (There is a Shortage of Labourforce in Latvia. Can Retirees Help?) Makroekonomika. Retrieved: https://www.makroekonomika.Iv/latvija-trukstdarbaspeka-vai-pensionari-var-palidzet. Access: 28.03.2021.

17. Orimo, H., Suzuki, T., Hosoi, T., Ito, H., Araki, A., Sawabe, M. (2006). Reviewing the Definition of 'Elderly'. Geriatrics and Gerontology International, Vol. 6, pp. 149-158. DOI: 10.1111/j.1447-0594.2006.00341.x

18. Schwab K. (Ed.). (2013). The Global Competitiveness Report 2013-2014. Geneva: World Economic Forum.

19. SEB Bank. (2012). Par jaunakajam tendencem pensiju joma (On the Latest Trends in Pensions). Sociological esurvey, $n=1450$ respondents. Retrieved: https://www.manapensija.lv/lv/blog/2012/01/latvijas-iedzivotajilabak-vecumdienas-strada-neka-sodien-kraj-pensijai/. Access: 28.03.2021.

20. Special Eurobarometer 378. (2012). Active Ageing. Study Report. Retrieved: https://ec.europa.eu/commfrontoffice/publicopinion/archives/ebs/ebs_378_en.pdf. Access: 28.03.2021.

21. Susskind, D. (2020). A World without Work: Technology, Automation and How We Should Respond. Metropolitan Books.

22. World Bank. (2021). The Active Ageing Challenge for Longer Working Lives in Latvia. Overview Report: Main Messages and Policy Recommendations. Retrieved: http://pubdocs.worldbank.org/en/809031443642635084/WB-Latvia-Active-Aging-Exec-Summary.pdf. Access: 28.03.2021.

23. World Health Organization. (2002). Active Ageing: A Policy Framework. Retrieved: https://apps.who.int/iris/bitstream/handle/10665/67215/WHO_NMH_NPH_02.8.pdf;jsessionid=E26F3F2CCBD7 88FC4AFB43C5C624F829?sequence=1. Access: 28.03.2021. 